\title{
IMPLIKASI YURIDIS PENGELOLAAN PERTAMBANGAN DALAM ASPEK KEHIDUPAN SOSIAL EKONOMI MASYARAKAT
}

\author{
M. Iqbal Asnawi \\ Dosen Fakultas Hukum Universitas Samudra Langsa \\ mhdiqbalasnawi@yahoo.com
}

\begin{abstract}
The enactment of Law No. 4 of 2009 concerning Mineral and Coal Mining is based on the consideration that the management and exploitation of the potential of minerals and coal can be carried out independently, reliably, transparently, competitively, efficiently and environmentally, in order to ensure sustainable national development. The purpose of State control over natural resources is essentially to provide real added value to the national economy in an effort to achieve prosperity and prosperity in an equitable manner. In the name of globalization and the internationalization of mining activities in Indonesia today there is little involvement of foreign parties as investors with the hope of being able to increase foreign exchange, taxes and technology transfer from this activity. But the creation of a situation that contradicts the justice of the people thus overrides the main objective for the management of Indonesia's natural resources, namely for the greatest prosperity of the people of Indonesia. Mining business has so far triggered a variety of serious problems, ranging from violations of rules and laws, social and horizontal conflicts, uncontrolled environmental damage, and economic inequality in the community. This situation can be observed by the government as the manager, supervisor and authority holder in making policies in the mining sector

Keywords: Mining, Social Economy, Society
\end{abstract}

Abstrak, Berlakunya Undang Undang Nomor 4 Tahun 2009 tentang Pertambangan Mineral dan Batubara didasarkan pada pertimbangan agar pengelolaan dan pengusahaan potensi mineral dan batubara dapat dilakukan secara mandiri, andal, transparan, berdaya saing, efisien, dan berwawasan lingkungan, guna menjamin pembangunan nasional secara berkelanjutan. Tujuan penguasaan Negara atas sumber daya alam pada hakekatnya adalah memberi nilai tambah secara nyata bagi perekonomian nasional dalam usaha mencapai kemakmuran dan kesejahterahan rakyat secara berkeadilan. Atas nama globalisasi dan internasionalisasi kegiatan pertambangan di Indonesia saat ini tidak sedikit melibatkan pihak asing sebagai investor dengan harapan mampu meningkatkan devisa, pajak, dan alih tekhnologi dari kegiatan ini. Namun terciptanya keadaan yang bertentangan keadilan masyarakat sehingga mengesampingkan tujuan utama bagi pengelolaan sumber daya alam Indonesia yakni untuk sebesar-besar kemakmuran rakyat Indonesia. Usaha pertambangan hingga sekarang telah memicu beragam masalah serius, mulai dari pelanggaran aturan dan hukum, konflik sosial dan horizontal, kerusakan lingkungan tidak terkendali, serta ketimpangan perekonomian di masyarakat. Keadaan ini dapat dicermati pemerintah selaku pengelola, pengawas dan pemegang kewenangan dalam mengambil kebijakan di bidang pertambangan.

Kata Kunci : Pertambangan, Sosial Ekonomi, Masyarakat 


\section{Pendahuluan}

Program Pembangunan Nasional (Propenas) ${ }^{1}$ sudah menetapkan tujuan dan arah pembangunan nasional yakni berusaha mewujudkan masyarakat adil dan makmur dengan mewujudkannya dalam pembangunan di berbagai bidang, diantaranya bidang ekonomi. Pembangunan ekonomi identik dengan pembangunan sektor-sektor ekonomi yang terdapat di Indonesia, seperti ; sektor pertanian, kehutanan, perikanan, peternakan, pertambangan, industri, perdagangan, jasa-jasa dan lain-lain. ${ }^{2}$ Landasan perekonomian Indonesia secara konstitusional juga dinyatakan dalam Pasal 33 Undang Undang Dasar 1945 (UUD 1945), sistem perekonomian disusun untuk mewujudkan demokrasi ekonomi dan dijadikan dasar pelaksanaan pembangunan ekonomi.

Sistem perekonomian Indonesia yang berdasarkan Pancasila dan UUD 1945 disebut sistem ekonomi demokrasi. Dengan demikian sistem ekonomi demokrasi dapat didefinisikan sebagai suatu sistem perekonomian nasional yang merupakan perwujudan dari falsafah Pancasila dan UUD 1945 yang berasaskan kekeluargaan dan kegotongroyongan dari, oleh, dan untuk rakyat di bawah pimpinan dan pengawasan pemerintah.

Pada sistem demokrasi ekonomi, pemerintah dan seluruh rakyat baik golongan ekonomi lemah maupun pengusaha aktif dalam usaha mencapai kemakmuran bangsa. Selain itu, negara berperan dalam merencanakan, membimbing, dan mengarahkan kegiatan perekonomian. Dengan demikian terdapat kerja sama dan saling membantu antara pemerintah, swasta, dan masyarakat. ${ }^{3}$ Suatu negara yang berdaulat mempunyai otoritas untuk mengatur negaranya termasuk masalah perekonomian. Artinya, setiap aktivitas yang dilakukan oleh masyarakat atau penduduk dinegara tersebut harus mengikuti aturan yang ditentukan oleh negara. Demikian juga halnya dengan Indonesia, yang secara tegas telah mencantumkan dalam Undang Undang Dasarnya, bahwa Indonesia adalah negara hukum. ${ }^{4} \mathrm{Hal}$ ini berarti seluruh aktivitas harus didasarkan pada norma-norma hukum yang ada tidak terkecuali dalam menjalankan kegiatan dalam dunia usaha dalam hal ini melakukan kegiatan usaha pertambangan.

Pengaturan tentang pertambangan di Indonesia saat ini di atur dalam Undang Undang Nomor 4 Tahun 2009 tentang Pertambangan Mineral dan Batubara

\footnotetext{
1 Mengenai Propenas diatur dalam Undang-undang No. 25 Tahun 2000 tentang Program Pembangunan Nasional Tahun 2000-2004

${ }^{2}$ Aminuddin Ilmar, Hukum penanaman Modal di Indonesia, (Jakarta:Kencana Prenada Media Group,2007) hlm. 1. Hal ini sesuai dengan tujuan negara Indonesia yang terdapat dalam pembukaan UUD 1945 yaitu melindungi segenap bangsa Indonesia, dan seluruh tumpah darah Indonesia dan untuk memajukan kesejahteraan umum, mencerdaskan kehidupan bangsa dan ikut melaksanakan ketertiban dunia yang berlandaskan kemerdekaan, perdamaian abadi dan keadilan sosial. Dalam tujuan negara tersebut disebutkan memajukan kesejahteraan umum. Jadi perekonomian nasional ini ditujukan bagi kemajuan dan kesejahteraan umum ${ }^{3} \mathrm{http}$ //wartawarga.gunadarma.ac.id/2012/01/pelaku-pelaku-ekonomi-dalam-sistem-perekonomianindonesia-3/, diakses tanggal 2 Juni 2018

${ }^{4}$ Sentosa Sembiring, Hukum Investasi, (Bandung : Nuansa Aulia, 2010) hlm. 13. Selanjutnya disebutkan bahwa Undang-undang Dasar atau konstitusi yang dimaksud disini adalah UndangUndang Dasar Tahun 1945 (UUD 1945) sebagaimana telah dilakukan beberapa kali diadakan perubahan. Dalam perubahan terakhir dengan tegas disebutkan Negara Indonesia adalah negara hukum (Lihat Pasal 1 ayat 3 UUD 1945)
} 
menggantikan Undang Undang sebelumnya yaitu Undang Undang Nomor 11 Tahun1967 tentang Ketentuan Ketentuan Pokok Pertambangan. Pertimbangan untuk menggantikan dengan Undang Undang yang baru adalah perkembangan nasional maupun internasional, sehingga dibutuhkan perubahan peraturan perundang-undangan di bidang pertambangan mineral dan batubara yang dapat mengelola dan mengusahakan potensi mineral dan batubara secara mandiri, andal, transparan, berdaya saing, efisien, dan berwawasan lingkungan, guna menjamin pembangunan nasional secara berkelanjutan ${ }^{5}$. Undang Undang Nomor 4 Tahun 2009 tentang Pertambangan Mineral dan Batubara memaknai Pertambangan sebagai sebagian atau seluruh tahapan kegiatan dalam rangka penelitian, pengelolaan dan pengusahaan mineral atau batubara yang meliputi penyelidikan umum, eksplorasi, studi kelayakan, konstruksi, penambangan, pengolahan dan pemurnian, pengangkutan dan penjualan, serta kegiatan pascatambang ${ }^{6}$. Seluruh rangkaian kegiatan tersebut merupakan tahapan-tahapan yang harus dilalui dalam kegiatan usaha pertambangan dan seluruh pengaturannya diatur dalam regulasi pertambangan serta peraturan-peraturan terkait lainnya ${ }^{7}$.

Dari rangkaian dan tahapan kegiatan pertambangan diatas dapat dilihat bahwa kegiatan pertambangan memerlukan keahlian yang khusus dan menggunakan tekhnologi yang canggih dalam pelaksanaannya. Disamping itu kegiatan pertambangan mempunyai keterkaitan yang sangat erat dengan keberadaan lingkungan hidup dan masyarakat disekitar wilayah pertambangan, sehingga membutuhkan tenaga ahli dan tekhnologi yang mumpuni mulai dari tahap awal penelitian sampai dengan kegiatan reklamasi dan pasca tambang.

Kegiatan pertambangan sudah sepatutnya mendapat pengawasan yang ekstra ketat dari pemerintah sebagai pihak yang berwenang memberikan izin bagi usaha pertambangan tersebut.Karena kegiatan ini merupakan kegiatan yang bersentuhan langsung dengan kehidupan masyarakat disekitar pertambangan disamping juga

\footnotetext{
${ }^{5}$ Lihat konsideran menimbang poin c Undang Undang Nomor 4 Tahun 2009 tentang Pertambangan Mineral dan Batubara, selanjutnya didalam penjelasan umum disebutkan bahwaundang-undang Nomor 11 Tahun 1967 tentang Ketentuan Ketentuan Pokok Pertambangan yang materi muatannya bersifat sentralistik sudah tidak sesuai dengan perkembangan situasi sekarang dan tantangan di masa depan. Di samping itu, pembangunan pertambangan harus menyesuaikan diri dengan perubahan lingkungan strategis, baik bersifat nasional maupun internasional.Tantangan utama yang dihadapi oleh pertambangan mineral dan batubara adalah pengaruh globalisasi yang mendorong demokratisasi, otonomi daerah, hak asasi manusia, lingkungan hidup, perkembangan teknologi dan informasi, hak atas kekayaan intelektual serta tuntutan peningkatan peran swasta dan masyarakat.

${ }^{6}$ Lihat Pasal 1 ayat 1 Undang Undang Nomor 4 Tahun 2009 tentang Pertambangan Mineral dan Batubara

${ }^{7}$ Beberapa rangkaian kegiatan pertambangan telah di buat peraturan tekhnisnya berupa Peraturan Pemerintah sesuai amanat Undang Undang itu sendiri. Diantaranya Peraturan Pemerintah Nomor 22 Tahun 2010 tentang Wilayah Pertambangan, Peraturan Pemerintah Nomor 23 Tahun 2013 tentang Pelaksanaan Kegiatan Usaha Pertambangan Mineral dan Batubara, Peraturan Pemerintah Nomor 24 Tahun 2012 tentang Perubahan Atas Peraturan Pemerintah Nomor 23 Tahun 2013 tentang Pelaksanaan Kegiatan Usaha Pertambangan Mineral dan Batubara, Peraturan Pemerintah Nomor 55 Tahun 2010 tentang Pembinaan dan Pemgawasan Penyelenggaraan Pengelolaan Usaha Pertambangan Mineral dan Batubara, Peraturan Pemerintah Nomor 78 Tahun 2010 tentang Reklamasi dan Pasca Tambang.
} 
membawa dampak yang serius terhadap lingkungan hidup.Sehingga pemerintah tidak boleh hanya melihat kegiatan pertambangan ini dari sisi komersialnya saja, namun dari sudut pandang sosial kemasyarakatan pun harus menjadi hal yang tidak kalah penting bagi pemerintah dalam membuat kebijakan di bidang ini.

Pertambangan merupakan sumber daya alam yang tidak dapat diperbaharui (Unrenewable $)^{8}$, untuk itu pengelolaannya dikuasai oleh negara dan dipergunakan untuk sebesar-besarnya kemakmuran rakyat. Hal ini secara tegas digariskan dalam Undang Undang Dasar 1945 Pasal 33 ayat (3) menyebutkan bahwa :

"Bumi dan air dan kekayaan alam yang terkandung didalamnya dikuasai oleh negara dan dipergunakan untuk sebesar-besarnya kemakmuran rakyat"

Mineral dan batubara yang terkandung dalam wilayah hukum pertambangan Indonesia merupakan kekayaan alam tak terbarukan sebagai karunia Tuhan Yang Maha Esa yang mempunyai peranan penting dalam memenuhi hajat hidup orang banyak, karena itu pengelolaannya harus dikuasai oleh Negara untuk memberi nilai tambah secara nyata bagi perekonomian nasional dalam usaha mencapai kemakmuran dan kesejahteraan rakyat secara berkeadilan? .

Berdasarkan uraian-uraian sebelumnya, dapat di rumuskan permasalahan ${ }^{10}$ yakni Bagaimana kesiapan regulasi pertambangan di Indonesia dalam menanggulangi dampak sosial ekonomi bagi masyarakat di sekitar tambang?

\section{Metode Penelitian}

Penulisan ini menggunakan metode dan pendekatan normatif, di karenakan objek telaah penelitian adalah norma hukum terkait pengaturan pertambangan dalam hukum positif di Indonesia. Tipologi penelitian normatif yang digunakan meliputi penelitian inventarisasi hukum positif, penemuan asas dan doktrin, serta sinkronisasi vertikal dan horizontal.Data yang dianalisis merupakan data skunder berupa bahan hukum primer, skunder, dan tertier yang dikumpulkan melalui studi kepustakaan.

\footnotetext{
${ }^{8}$ Salim HS, Hukum Penyelesaian Sengketa Pertambangan di Indonesia (Bandung : Pustaka Reka Cipta, 2013) hlm. 1, selanjutnya disebutkan bahwa sumber daya alam yang tidak dapat diperbaharui dapat dikategorikan seperti minyak dan gas bumi, emas, tembaga, perak, batubara dan sumber daya lainnya. Lihat juga Dedek Aprianto, Dampak Kegiatan Batubara terhadap Kondisi Sisial-Ekonomi Masyarakat di Kelurahan Loa Ipuh Darat, Tenggarong, Kutai Kartanegara,dalam : Jurnal Bumi Indonesia hlm. 290 disebutkan bahwa keberadaan sumberdaya alam yang memiliki potensi ekonomi perlu dilakukan pengelolaan agar dapat termanfaatkan secara maksimal dan berguna dalam meningkatkan taraf hidup masyarakat. Keberadaan kegiatan pertambangan batubara pada daerah penelitian merupakan suatu upaya dari pemerintah untuk dapat memanfaatkan potensi wilayah yang dimiliki oleh daerah tersebut.Khususnya batubara yang merupakan komoditas yang memiliki nilai ekonomi tinggi karena kegunaanya pada bidang energi.

${ }^{9}$ Lihat konsideran menimbang poin a Undang Undang Nomor 4 Tahun 2009 tentang Pertambangan Mineral dan Batubara

${ }^{10}$ Permasalahan timbul apabila terjadi atau terdapat adanya kesenjangan antara Does Sollen dan Das Sein, yaitu apabila ada perbedaan atau ketidak sesuaian antara apa yang seharusnya dengan apa yang ada dalam kenyataan, antara apa yang diperlukan dengan apa yang tersedia, atau adanya kesenjangan antara harapan yang dicita-citakan dengan kenyataan yang ditemui. Lihat Bahder Johan Nasution, Metode Penelitian Hukum, (Bandung : Mandar maju, 2008) hlm. 55-56
} 
Analisis data dilakukan secara kualitatif tentang pendekatan analisis menggunakan pendekatan perundang-undangan (statute approach) dan pendekatan konseptual (conceptual approach).Kedua pendekatan analisis ini dipandang sesuai karena objek analisis adalah peraturan perundang-undangan dan konsep pertambangan itu sendiri.

\section{Pembahasan}

\section{A. Penguasaan Negara atas Kegiatan Pertambangan}

Ketentuan tentang hak menguasai Negara atas bahan tambang memang tidak disebut secara ekspilisit dalam Pasal 33 ayat 3 UUD 1945. Namun pengertiannya agak sedikit samar ada tertuang dalam Undang Undang No. 5 Tahun 1960 tentang Pokok Agraria (UUPA). Menurut UUPA pengertian bumi termasuk di dalamnya adalah bahan tambang. Dalam ketetuan Pasal 1 ayat 4 UUPA disebutkan dalam pengertian bumi, selain permukaan bumi termasuk pula tubuh bumi di bawahnya serta yang berada di bawah air.

Apa yang termaktub dalam ketetuan di atas memberikan sebuah pemikiran otentik tentang apa yang di anggap dengan istilah bumi. Pengertian bumi dalam UUPA meliputi permukaan bumi, berikut apa yang ada di bawahnya serta yang terdapat di dalam air. Berdasarkan tafsiran pasal tersebut dapat pula dimasukkan tentang bahan tambang sebagai bagian dari bumi. ${ }^{11}$

Penguasaan negara dalam pengelolaan pertambangan dilaksanakan oleh Pemerintah, dalam hal ini adalah pemerintah pusat dan pemerintah daerah ${ }^{12}$.Masingmasing mempunyai kewenangan dalam hal pengelolaan pertambangan mineral dan batubara.Namun demikian, pemerintah sendiri tidak mampu untuk melakukan usaha pertambangan atas sumber daya alam yang kita miliki tersebut.Untuk melaksanakan kegiatan tersebut pemerintah sendiri memberikan kewenangan kepada pihak lainnya untuk melakukan usaha pertambangan atas sumber daya alam tambang ${ }^{13}$.Regulasi pertambangan sendiri memberikan wewenang kepada orang atau badan usaha untuk melakukan usaha pertambangan atas sumber daya alam tambang yang dimiliki negara Indonesia. Pemerintah selanjutnya memberikan kesempatan kepada badan usaha yang berbadan hukum Indonesia, koperasi, perseorangan, maupun masyarakat setempat untuk melakukan pengusahaan mineral dan batubara berdasarkan izin, yang sejalan dengan otonomi daerah, diberikan oleh Pemerintah dan/atau pemerintah daerah sesuai dengan kewenangannya masing-masing ${ }^{14}$

Tujuan penguasaan negara atas sumber daya alam pada hakekatnya adalah memberi nilai tambah secara nyata bagi perekonomian nasional dalam usaha mencapai

\footnotetext{
${ }^{11}$ Haris Retno Susmiyati, Tinjauan Terhadap Permasalahan dalam Pengusahaan Pertambangan Batu Bara di Indonesia, Jurnal Risalah Hukum, Edisi Nomor 2, Desember 2005, hlm. 3

${ }^{12}$ Lihat Pasal 4 dan Pasal 5 Undang Undang Nomor 4 Tahun 2009 tentang Pertambangan Mineral dan Batubara

${ }^{13}$ Salim HS.Op.Cit hlm. 5, selanjutnya disebutkan bahwa dalam realitasnya usaha pertambangan ini banyak dilakukan oleh swasta nasional, asing, maupun dari gabungan badan hukum asing dengan badan hukum swasta. Untuk melaksanakan usaha pertambangan itu Pemerintah Indonesia harus mengadakan kontrak kerjasama dengan badan hukum diatas.

${ }^{14}$ Lihat penjelasan umum Undang Undang Nomor 4 Tahun 2009 tentang Pertambangan Mineral dan Batubara
} 
kemakmuran dan kesejahterahan rakyat secara berkeadilan. Hal ini sesuai dengan apa yang menjadi pokok pikiran dari regulasi pertambangan itu sendiri. Pokok-pokok pikiran itu antara lain :

1. usaha pertambangan harus memberi manfaat ekonomi dan sosial yang sebesar-besar bagi kesejahteraan rakyat Indonesia;

2. usaha pertambangan harus dapat mempercepat pengembangan wilayah dan mendorong kegiatan ekonomi masyarakat/pengusaha kecil dan menengah serta mendorong tumbuhnya industri penunjang pertambangan; dan

3. dalamrangka terciptanya pembangunan berkelanjutan, kegiatan usaha pertambangan harus dilaksanakan dengan memperhatikan prinsip lingkungan hidup, transparansi, dan partisipasi masyarakat. ${ }^{15}$

Sementara itu yang menjadi tujuan pengelolaan mineral dan batubara adalah dalam rangka mendukung pembangunan nasional yang berkesinambungan adalah :

1. menjamin efektivitas pelaksanaan dan pengendalian kegiatan usaha pertambangan secara berdaya guna, berhasil guna, dan berdaya saing;

2. menjamin manfaat pertambangan mineral dan batubara secara berkelanjutan dan berwawasan lingkungan hidup;

3. menjamin tersedianya mineral dan batubara sebagai bahan baku dan/atau sebagai sumber energi untuk kebutuhan dalam negeri;

4. mendukung dan menumbuhkembangkan kemampuan nasional agar lebih mampu bersaing di tingkat nasional, regional, dan internasional;

5. meningkatkan pendapatan masyarakat lokal, daerah, dan negara, serta menciptakan lapangan kerja untuk sebesar besar kesejahteraan rakyat; dan

6. menjamin kepastian hukum dalam penyelenggaraan kegiatan usaha pertambangan mineral dan batubara. ${ }^{16}$

Penguasaan oleh negara melalui pengelolaan pertambangan oleh pemerintah seyogianya memberikan angin segar bagi masyarakat Indonesia, khususnya bagi masyarakat yang langsung terkena dampak dari kegiatan pertambangan tersebut. Merujuk kepada regulasi pertambangan serta pokok-pokok pikiran yang telah dipaparkan sebelumnya, setidaknya pemerintah telah memberikan harapan yang besar bagi tercapainya kesejahterahan masyarakat yang berkeadilan. Namun kondisi ini sangat berseberangan dengan apa yang terjadi saat ini jika melirik kepada apa yang dicapai selama ini oleh pemerintah selaku pengelola dan pemberi izin bagi usaha pertambangan. Masih banyak sekali dampak negatif yang dirasakan bagi masyarakat dibandingkan dengan manfaat yang di peroleh, kondisi ini tidak sedikit memicu konflik di masyarakat dengan dalih mencari keadilan atas dampak yang mereka terima atas kegiatan pertambangan disekitar wilayah masyarakat tersebut.

Konflik yang terjadi di permukaan pada umumnya terjadi antara masyarakat dengan pemegang Izin Usaha Pertambangan (IUP). Kondisi ini menyebabkan pemegang

\footnotetext{
${ }^{15}$ Lihat pokok-pokok pikiran regulasi pertambangan ini di dalam penjelasan umum Undang Undang Nomor 4 Tahun 2009 tentang Pertambangan Mineral dan Batubara

${ }^{16}$ Lihat Pasal 3 Undang Undang Nomor 4 Tahun 2009 tentang Pertambangan Mineral dan Batubara
} 
IUP tidak leluasa dalam melaksanakan usaha pertambangan, padahal mereka telah mengantongi izin yang sah dari pemerintah. Namun tidak serta merta kegiatan pertambangan langsung dapat dilaksanakan sesuai yang diharapkan bagi pemegang izin tersebut. Masyarakat sekitar wilayah pertambangan akan berhadapan dengan mereka di lapangan, sehingga para pelaku usaha pertambangan tidak sedikit yang merugi akibat konflik dengan masyarakat sekitar wilyah pertambangan. Investasi yang dilakukan untuk usaha pertambangan tidaklah sedikit, walaupun keuntungan yang dihasilkan dari kegiatan ini pun cukup menggiurkan.

Konsepsi mengenai hak menguasai Negara merupakan persoalan yang serius dalam praktik pertambangan di Indonesia.Konsepsi ini kerap melahirkan beragai kebijakan salah kaprah yang mempunyai dampak yang besar bagi masyarakat lokal.Dari konsepsi ini pula tercipta tindakan serta keputusan Negara yang tidak bijaksana yang dirasakan oleh masyarakat.

\section{B. Keterlibatan Asing dan Keberadaan Investor}

Kegiatan pertambangan di Indonesia saat ini tidak sedikit melibatkan pihak asing yang ikut dalam kegiatan usaha pertambangan.Kondisi ini bagian dari internasionalisasi kegiatan pertambangan disamping dalih alih tekhnologi merupakan hal yang diharapkan dari kegiatan ini. Disamping itu, arus globalisasi juga tidak membolehkan Indonesia untuk menutup mata dengan dunia luar, disamping Indonesia juga merupakan anggota dari beberapa organisasi internasional termasuk bidang perdagangan. Namun keadaan ini bukan berarti mengesampingkan keberadaan masyarakat yang berada di sekitar wilayah pertambangan yang terkena dampak atas kegiatan pertambangan tersebut. Dengan dalih pembangunan perekonomian nasional, pemasukan devisa dan pajak serta pendapatan negara dan pendapatan daerah, keberadaan kegiatan pertambangan bukan menjadi alasan pembenar bagi keadaan yang melukai rasa keadailan masyarakat. Sehingga tujuan utama bagi pengelolaan sumber daya alam Indonesia untuk sebesar-besar kemakmuran rakyat Indonesia dapat dikesampingkan.

Salah satu faktor yang menjadi pertimbangan bagi investor untuk menanamkan modalnya adalah masalah kepastian hukum. Berbagai ketentuan hukum yang terkait dengan investasi dirasakan perlu untuk disesuaikan dengan berbagai perjanjian multilateral, regional maupun bilateral yang diikuti oleh pemerintah. Masyarakat mengharapkan adanya kepastian hukum, karena dengan adanya kepastian hukum masyarakat akan lebih tertib. Hukum bertugas menciptakan kepastian hukum karena bertujuan ketertiban masyarakat. Tanpa kepastian hukum orang tidak tahu apa yang harus diperbuatnya dan akhirnya timbul keresahan. Tetapi terlalu menitikberatkan pada kepastian hukum, terlalu ketat mentaati peraturan hukum akibatnya kaku dan akan menimbulkan rasa tidak adil. Apapun yang terjadi peraturannya adalah demikian dan harus ditaati dan dilaksanakan. Undang-Undang itu sering terasa kejam apabila 
dilaksanakan secara ketat. lex dura, sed tamen scripta (undang-undang itu kejam, tetapi memang demikianlah bunyinya)"17

Sekalipun kehadiran investor membawa manfaat bagi penerima modal, ${ }^{18}$ disisi lain investor yang hendak menanamkan modalnya juga tidak terlepas dari orientasi bisnis (busines oriented), apakah modal yang di investasikan aman dan bisa menghasilkan keuntungan. Oleh karena itu, terdapat beberapa faktor penentu bagi investor dalam berinvestasi, yaitu apakah investasi memberikan tambahan nilai kepada perusahaan melalui penjualan produknya.Demikian halnya juga suku bunga merupakan harga atau biaya yang harus dibayar dalam meminjamkan uang untuk suatu periode tertentu dan ekpektasi keuntungan.Dengan demikian para investor melakukan investasi untuk mendapatkan keuntungan atas investasi yang dilakukan.Selain pertimbangan ekonomi, investor juga mempertimbangkan non ekonomi seperti jaminan keamanan, stabilitas politik, penegakan hukum dan sosial budaya merupakan faktor penentu yang tidak kalah pentingnya untuk menentukan keberhasilan investasi ${ }^{19}$.

Suatu pemerintah yang mempertimbangkan sungguh-sungguh setiap usulan penanaman modal khususnya penanaman modal asing, dihadapkan pada dilema antara hasrat untuk menggunakan penanaman modal tersebut sebagai sarana mencapai sasaran nasional tertentu dan adanya ketakutan kalau bermacam-macam nilai nasional akan terancam oleh penanaman modal tersebut. Yang mendukung dan yang melawan sulit untuk ditimbang atau dihitung dengan cara yang memuaskan. Godaan-godaan mengizinkan teori lasses-faire berlaku cukup besar, namun karena pemerintah semakin jeli ketidaksamaan antara kepentingan nasional dan bisnis dan lebih berminat untuk menetapkan pembangunan ekonomi dalam pengawasan seksama yang terkoordinasi,

\footnotetext{
17 Sudikno Mertokusumo, Mengenal Hukum (Suatu Pengantar), (Yogyakarta:Liberty,1988) Cetakan ke-1 hlm. 136

${ }^{18}$ Gunarto Suhardi, Beberapa Elemenn Penting dalam Hukum Perdagangan Internasional, (Yogyakarta : Universitas Atmajaya, 2004) hlm. 45, disebutkan bahwa beberapa manfaat daari kegiatan Investasi antara lain : a. memeberikan kesmpatan kerja bagi penduduk, b. mempunyai kekuataan penggandaan dalam ekonomi lokal, c. memberikan residu baik berupa peralatan maupun alih tekhnologi, d. bila produksi di ekspor memberikan jalan pemasaran yang dapat di runtut oleh pengusaha lokal disampin seketika memberikan tambahan devisa dan pajak bagi negara, e. lebih tahan terhadap fluktuasi bunga dan valuta asing, f. memberikan perlindungan politik dan keamanan wilayah karena bila investor berasal dari negara kuat niscaya bantuan keamanan juga akan diberikan. Lihat dan bandingkan dengan Salim HS dan Budi Sutrisno, Hukum Investasi di Indonesia (Jakarta : Rajawali, 2008). hlm. 88, disebutkan bahwa dampak positif dari kehadiran investasi asing antara lain: a. memberikan modal kerja, b. mendatangkan keahlian , manajerial, ilmu pengetahuan, modal, dan koneksi pasar, c. meningkatkan pendapatan uang asing melalui aktivitas ekspor oleh perusahaan multinasional, d. negara penerima tidak merisaukan atau menghadapi resiko ketika suatu PMA yang masuk ke negerinya ternyata tidak mendapat untung dari modal yang diterimanya dan e. membantu upaya-upaya pembangunan kepada perekonomian negara-negara penerima modal asing.

${ }^{19}$ Sentosa Sembiring, Op.Cit. hlm. 9, lihat juga Bank Indonesia, Survey Faktor-Faktor Nonekonomi Yang Mempengaruhi Iklim Investasi di Sulawesi Selatan Triwulan II-2007, Kajian Ekonomi Regional Sulawesi Selatan.hlm. 33
} 
mereka merasa lebih sulit membiarkan hal-hal tersebut berjalan sesuai dengan kemauan arah bisnis swasta ${ }^{20}$.

Roberto M. Unger mengungkapkan bahwa iamengkritik liberalisme yang menurutnya menghasilkan perubahan moral individu dan politik masyarakat modern yang berbahaya. Lisberalisme membengkokan moral, intelektual, dan sisi spiritual seseorang. Maka dia melontarkan suatu kritik yang menyeluruh. Dia menemukan "struktur mendalam" dari liberalisme yang terdiri dari enam prinsip; (1) rasionalitas dan hawa nafsu, (2) keinginan yang sewenang-wenang, (3) Analisis, (4) Aturan-aturan dan nilainilai, (5) nilai subyektif, dan (6) individualisme. ${ }^{21}$

Melalui kacamata kelompok-kelompok masyarakat yang dominan dan para pembicara intelektualnya, masyarakat modern memandang dirinya sebagai peradaban yang sangat individualistis, yang aturan dan kebebasannya dijamin oleh hukum.Meski demikian, ikatan interdepndensi tak mungkin lebih ketat daripada ikatan yang terjadi.Peraturan-peraturan hukum (legal rules) memang tampak berperan, tetapi kecil sekali artinya dalam membina kehidupan sosial. ${ }^{22}$ Diharapkan produk hukum suatu negara dapat menjembatani kepentingan masyarakat dan penguasa.Sehingga kebijakan yang dikeluarkan tidak hanya menguntungkan salah satu pihak saja. Hukum di jadikan sandaran bagi para pembuat kebijakan untuk menghendaki apa yang diinginkannya tanpa harus mempertimbangkan akibat dari pemberlakuan hukum tersebut.

Sebagaimana disampaikan sebelumnya bahwa perubahan regulasi pertambangan saat ini adalah keharusan untuk menyesuaikan perubahan lingkungan strategis, baik

\footnotetext{
${ }^{20}$ Detlev F. Vagts Dalam Peranan Hukum dalam Perekonomian di Negara Berkembang.Penyunting : T. Mulya Lubis dan Richard M. Buxbaum,( Jakarta : Yayasan Obor Indonesia, 1986). Cet. I. hlm. 68. Lihat dan bandingkan dengan Erman Rajagukguk, Pembaharuan Hukum Indonesia Dalam Era Globalisasi : Suatu Pemikiran Untuk mendorong Pertumbuhan Ekonomi dan Pengentasan Kemiskinan, dalam Agenda Bangsa Pasca 50 Tahun Indonesia Merdeka (Jakarta : Cides, 1995), hlm. IV.5, disebutkan bahwa Pada tahun 1970 pengkajian hukum dalam kaitannya dengan pembangunan hanya mengkaji bagaimana hukum dapat mendorong pertumbuhan ekonomi. Salah satu fokus kajiannya adalah bagaimana peranan hukum sebagai alat perubahan sosial (law is tool og social engineering) dari masyarakat sosial menuju masyarakat modern. Dua puluh tahun kemudian tepatnya pada tahun 1990 kajian hukum rekayasa sosial ini telah bergeser sejalan dengan terjadinya arus era globalisasi yang ditandai dengan era perdagangan bebas (free trade). Dengan kata lain, kajian hukum telah beralih dari lingkup domestik ke masalah kajian-kajian global.

${ }^{21}$ Dia menunjukan antinomi yang ada antara rasionalitas dan hawa nafsu, antara aturan dan nilai. Untuk menyelesaikan antinomi tersebut, ada dua jalan, yaitu; pertama, suatu penyelesaian politis untuk mewujudkan transformasi kondisi kehidupan sosial di mana dominasi harus dihilangkan karena menimbulkan nilai yang kebetulan dan berubah-ubah. Kedua, suatu revolusi teroritis dibutuhkan untuk menciptakan suatu sistem berpikir yang berdasar pada kebaikan umat manusia.Dalam masyarakat liberal, ternyata kesejahteraan yang menjadi tujuan utama doktrin laize faire tidak bisa terpenuhi karena adanya ketidaksamaan kekuatan dan nafsu keserakahan manusia sehingga menciptakan penderitaan pada sebagian besar anggota masyarakat. Kesejahteraan hanya dinikmati oleh sekelompok orang yang memiliki kekuatan lebih sehingga dapat bersaing. Lihat James Boyle, The Politic of Reason: Critical Legal Theory And Local Social Thought, (University of Pennsylvania Law Review, 1985), hlm. 4.

${ }^{22}$ Roberto M. Unger, Teori Hukum Kritis : Posisi Hukum dalam Masyarakat Modern, diterjemahkan dari Law and Modern Society : Toward a Crtitism of Social Teory, Penerjemah : Dariyatno dan Derta Sri Widowatie (Bandung : Nusa Media, 2008) Cet. II. hlm. 48
} 
bersifat nasional maupun internasional.Tantangan utama yang dihadapi oleh pertambangan mineral dan batubara adalah pengaruh globalisasi yang terjadi.Bismar Nasution mengungkapkan bahwa Fenomena ekonomi dunia yang ada sekarang ini membuat banyak negara, termasuk Indonesia dituntut untuk mengikuti kecenderungan arus globalisasi yang mengarah pada penduniaan dalam arti "peringkasan" atau "perapatan" dunia (compression of the world) di bidang ekonomi. Seiring dengan itu, globalisasi ekonomi yang akhir-akhir ini semakin dikembangkan pula oleh prinsip liberalisasi perdagangan ataupun perdagangan bebas lainnya telah mempangaruhi hukum setiap negara, terutama pada negara-negara yang terlibat dalam perdagangan bebas tersebut. $^{23}$

Pengaruh globalisasi sangat tampak mempengaruhi kebijakan penguasa, sehingga pertimbangan moral sangat sedikit dan sebatas formalitas saja dalam mengeluarkan kebijakan. Produk hukum yang dibuat juga lebih mementingkan hawa nafsu untuk mendapatkan apa yang diinginkan sebagai cita yang hendak di capai, sehingga hukum sangat sedikit sekali memberikan pengaruhnya tehadapat tujuan kesejahterahan masyararakat yang berkeadilan. Kesan kesewenang-wenangan muncul ketika hukum dipaksakan untuk berlaku walaupun hasilnya tidak membawa manfaat bagi kepentingan masyarakat.

\section{Dampak Sosial Ekonomi pada Masyarakat di sekitar Pertambangan}

Dalam konteks kehidupan sosial masyarakat di sekitar lokasi pertambangan, hubungan sosial terbentuk karena kesamaan kepentingan di atas pengelolaan sumbersumber produksi setempat, kesamaan atas tanah dan kekayaan alam, serta kesamaan sejarah dan adat budaya. Direnggutnya penguasaan masyarakat atas tanah dan kekayaan alam menyebabkan fondasi modal sosial mereka lenyap. Keadaan ini pada umumnya akan dan berdampak pada:

1. Lenyapnya daya ingat sosial, hilangnya tatanan nilai sosial yang dulunya dimiliki komunitas;

2. Putusnya hubungan silahturami antar warga menyebabkan perpecahan, persengketaan dan bahkan ke taraf konflik (saling melenyapkan eksistensi satu sama lain). Mekanisme resolusi konflik tradisional yang telah hidup dalam komunitas tidak lagi dijadikan kontrol dalam kehidupan sosial.

3. Menurunnya daya tahan tubuh, karena merosotnya mutu kesehatan, mental warga, dan seringkali munculnya penyakit-penyakit baru, baik penyakit yang berupa

\footnotetext{
${ }^{23}$ Bismar Nasution, Hukum Kegiatan Ekonomi, (Bandung:Book Terace \& Library, 2007) Cet. II, hlm. 28. Selanjutnya disebutkan boleh dikatakan bahwa arus globalisasi ekonomi dan perdagangan bebas yang terjadi sekarang ini sangat sulit untuk ditolak kehadirannya dan harus diikuti mengingat kepentingan ekonomi negara masing-masing. Globalisasi ekonomi dn perdagangan bebas tersebut berkembang melalui perundingan dan perjanjian internasional. Lihat juga Lawrence M. Friedman, Legal Culture and the Welfare State: law and Society-An Introduction. (London:Harvard UniversityPress,1990) hlm. 89 yang mengatakan bahwa hukum itu tidak bersifat otonom, tetapi sebaliknya hukum bersifat terbuka setiap waktu terhadap pengaruh luar.
} 
metabolisme akut akibat pencemaran (udara, air, tanah dan bahan-bahan hayati yang dikonsumsi), penyakit menular (kelamin)dan penyakit lain yang dibawa oleh pekerja yang berasal dari luar daerah. ${ }^{24}$

Selain dampak sosial, kegiatan pertambangan juga akan berdampak kepada ekonomi masyarakat di sekitar wilayah pertambangan. Operasi pertambangan membutuhkan lahan yang luas, dipenuhi dengan cara menggusur tanah milik dan wilayah kelola rakyat. Hal ini akan berdampak pada kondisi-kondisi sebagai berikut :

1. Kehilangan sumber produksi (tanah dan kekayaan alam) melumpuhkan kemampuan masyarakat setempat menghasilkan barang-barang dan kebutuhan mereka sendiri.

2. Rusaknya tata konsumsi, lumpuhnya tata produksi menjadikan masyarakat makin tergantung pada barang dan jasa dari luar. Untuk kebutuhan sehari-hari mereka semakin lebih jauh dalam jeratan ekonomi. Uang tunai yang cendrung melihat tanah dan kekayaan alam sebagai faktor produksi dan bisa ditukar dengan sejumlah uang tidak lebih.

3. Rusaknya tata distribusi, kegiatan distribusi setempat semakin didominasi oleh arus masuknya barang dan jasa ke dalam komunitas. ${ }^{25}$

Selama ini dibangun opini publik bahwa pertambangan akan membawa kesejateraan dengan meningkatkan pendapatan ekonomi masyarakat setempat. Tetapi yang terjadi seperti yang dikemukakan sebelumnya, kekhawatiran yang terjadi adalah apa yang dijanjikan terkait peningkatan ekonomi rakyat akan berubah roman menjadi kuli di negeri sendiri.Tawaran akan pertambangan perlu dikaji secara cermat dengan melihat fakta-takta yang sudah ada. Bukan dengan pragramtis lalu pertambangan disetujui, setelah itu baru diakhiri dengan kekesalan

Dampak Sosialekonomi menurut Homenauck dapat dikategorikan ke dalam kelompok kelompok real impact dan special impact.Real impact adalah dampak yang timbul sebagai akibat dari aktivitas proyek, pra konstruksi, konstruksi, operasi dan pasca operasi, misalnya migrasi penduduk, kebisingan atau polusi udara.Special impact adalah suatu dampak yang timbul dari persepsi masyarakat terhadap resiko dari adanya proyek.Dampak pada kondisi sosial-ekonomi pada penelitian ini dikaji melalui peluang

\footnotetext{
${ }^{24}$ Wahana Lingkungan Hidup Nusa Tenggara Timur, dalam : Memahami Pertambangan, Dampak dan Tahapannya, http://walhintt.wordpress.com/2012/05/07/memahami-pertambangan-dampakdan-tahapannya/, diakses tanggal 5 April 2018

${ }^{25}$ Ibid, Lihat Juga Hardiyanti Dharma Pertiwi, Dampak Keberadaan Perusahaan Pertambangan Batubara Terhadap Aspek Ekologi, Sosial dan Ekonomi Masyarakat di Era Otonomi Daerah (Kasus: Kelurahan Sempaja Utara, Kecamatan Samarinda Utara, Kota Samarinda). (Skripsi: Institut Pertanian Bogor , 2011) disebutkan bahwa dampak pada kondisi fisik meliputi pencemaran air yang diakibatkan kontaminasi dengan limbah hasil sisa dari kegiatan pertambangan, pencemaran udara karena tercemar oleh gas hasil buangan dari kegiatan pertambangan, maupun polusi suara karena kegiatan pertambangan seperti (blasting) ataupun truk pengangkut barang tambang. Kerusakan jalan yang disebabkan oleh kegiatan pertambangan baik pengangkutan keperluan pertambangan seperti alat berat maupun kebutuhan bahan bakar juga turut memberikan dampak negatif terhadap kondisi fisik di daerah pertambangan. Dampak kondisi fisik merupakan dampak yang ditimbulkan oleh adanya aktivitas pertambangan pada kondisi pencemaran pada air, udara, polusi suara, kerusakan jalan dan pembukaan hutan di sekitar wilayah pertambangan
} 
berusaha, peningkatan pendapatan, perubahan mata pencaharian, perubahan perilaku masyarakat, kejadian konflik serta migrasi. ${ }^{26}$

Kehadiran kegiatan pertambangan tidak dipungkiri juga membawa dampak positif bagi masyarakat sekitar wilayah pertambangan. Dampak positif tersebut antara lain berupa bantuan dibidang sosial budaya, pendidikan dan perkebunan, masyarakat di sekitar areal pertambangan sebagian besar mendapat keuntungan dan pekerjaan tambahan. Namun yang disayangkan bantuan-bantuan tersebut didapatkan masyarakat bukan tanpa sebab, melainkan adanya arus tekanan masyarakat dalam menuntut perusahaan berlaku adil terhadap masyarakat, banyak konflik dan demo telah terjadi baik antara masyarakat dengan perusahaan maupun antara masyarakat dengan pemerintah. ${ }^{27}$

Kondisi seperti ini sudah pernah dilakukan penelitian yang mendalam oleh Salim $\mathrm{HS}^{28}$ yang disusun dalam desertasi berjudul "Penyelesaian sengketa tanah di Wilayah Kontrak Karya PT. Newmont Nusa Tenggara"(Studi Kasus Sengketa antara Masyarakat Desa Labangkar dan Desa Ropang Kecamatan Ropang Kabupaten Suabawa dengan PT. Newmont Nusa Tenggara), disebutkan bahwa keberadaan PT. Newmont Nusa Tenggara dalam melakukan kegiatan eksplorasi di wilayah Elang Dodo Ropang Sumbawa telah menimbulkan perubahan prilaku bagi masyarakat yang berada di Desa Labangkar dan Desa Ropang, Kecamatan Ropang Kabupaten Sumbawa.

Semula masyarakat yang berada di kedua desa tesebut hidup secara komunal (kelompok), harmonis (keselarsan), sembang serta menjunjung tinggi nilai-nlai kegotong royongan. Namun kini mayarakat tersebut telah terjadi perubahan prilaku yang sangat mendasar, yaitu masyarakat meminta kepada PT. Newmont Nusa Tenggara untuk menghentikan kegiatan eksplorasi karena tidak ada meminta persetujuan dari masyarakat. Masyarakat berpandangan bahwa tanah yang digunakan PT. Newmont merupakan tanah balo tolo yang ditinggalkan nenek moyang mereka 77 tahun yang lalu. Masyarakat meminta ganti rugi sebesar Rp. 100 juta/hektar, semua dilakukan dengan menunjukkan bukti-bukti, baik itu bukti sejarah, maupun bukti SPPT yang dikeluarkan oleh kantor pajak. Disamping itu masyarakt juga tidak mempermasalahkan tentang status tanah yang digunakan PT. Newmont, namun yang dipersoalkan adalah dampak jangka panjang dari penggunaan tanah dari kegiatan eksplorasi maupun eksploitasi. Dampak jangka panjangnya adalah menurunnya debit air yang berasal dari wilayah mereka, sehingga hasil pertanian yang dan perkebunan yan diusahakan mereka berkurang. Untuk itu masyarakat meminta PT. Newmont memberikan mereka dana pengembangan masyarakat sebesar Rp. 10 Milyar. Dana sebanyak itu nantinya akan digunakan untuk mengembangkan pendidikan, kesehatan, ekonomi bahkan dana untuk penelitan bagi kaum muda yang ada di desa. Permintaan dan tuntutan masyarakat belum dipenuhi karena PT. Newmont berpendapat bahwa pengembangan masyarakat baru akan dilakukan setelah kegiatan eksploitasi. Akibat tidak dipenuhinya permintaan tersebut, maka masyarakat melakukan perusakan terhadap base camp yang telah dibangun oleh PT.

\footnotetext{
${ }^{26}$ Sudharto P Hadi, Aspek Sosial Amdal. (Yogyakarta: Gadjah Mada University Press, 2005),

${ }^{27}$ Artikel Mengenal Dampak Pertambangan Bagi Masyarakat dan Lingkungan (Investigasi Lapangan),http://yathh.wordpress.com/2013/06/20/mengenal-dampak-pertambangan-bagimasyarakat-dan-lingkungan-investigasi-lapangan/, diakses tanggal 3 Mei 2018

${ }^{28}$ Salim HS, Op.Cit. hlm 10-13
} 
Newmont sehingga PT. Newmont menghentikan kegiatan eksplorasinya dan menderita kerugian yang cukup besar. Disamping itu kerugian juga diderita oleh masyarakat, pemerintah, pemerintah daerah.

Usaha pertambangan di tanah air hingga saat ini lebih banyak memicu beragam masalah serius, mulai dari pelanggaran aturan dan hukum, konflik sosial dan horizontal, kerusakan lingkungan tidak terkendali, hingga ujung-ujungnya tindakan kriminal dan kekerasan. Praktik usaha ini pun belum banyak memberikan kesejahteraan yang nyata bagi masyarakat ${ }^{29}$.Keadaan seperti ini harus dapat dicermati pemerintah selaku pengelola, pengawas dan pemegang kewenangan dalam mengambil kebijakan di bidang pertambangan.Karena kegiatan pertambangan seharusnya memberikan kontribusi yang signifikan bagi masyarakat, bukan malah menjadi suatu momok yang menakutkan bagi keberlangsungan hidupnya sehingga merampas rasa keadilan bagi masyarakat di sekitar wilayah pertambangan.

Indonesia adalah negara hukum (rechstaat) bukan negara kekuasaan

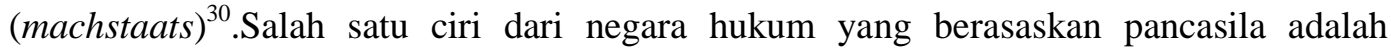
adanya keadilan sosial bagi seluruh rakyat Indonesia. ${ }^{31} \mathrm{Jika}$ keadilan sosial tersebut tercapai maka negara diharapkan dapat mengantarkan rakyat Indonesia menuju kepada kesejahterahan. Penyelenggaraan kesejahterahan umum (bestuurzoor) merupakan tugas dari negara yang berbentuk walfare state atau negara hukum yang baru dan dinamis atau negara hukum material atau negara hukum administratif. ${ }^{32}$

Masyarakat adalah himpunan individu-individu, yang masing-masing secara egoistis mengejar kepentingan mereka sendiri. Kesimpulan ini diambil berdasarkan pengalaman empiris. Karena pengalaman empiris merupakan satu-satunya sumber untuk pengetahuan ilmiah yangsah.Selanjutnya Paretomengungkapkan bahwa sosiologi harus bersifat logis dan eksperimental. Dia mencita-citakan sosiologi yang didasarkan atas kriteria matematika rasional, yang selalu sah dan tak berubah sehingga harus dibenarkan oleh setiap orang yang berakal-budi sehat dan yang berlandasan pada realitas yang merupakan obyek observasi inderawi. Tiap-tiap konsep, proposisi, dan teori harus berpangkal pada fakta yang ditinjau atau mungkin dapat ditinjau. ${ }^{33}$

\footnotetext{
${ }^{29}$ Artikel Tambang Banyak Picu Masalah, http://indonesiacompanynews.wordpress.com/2012/02/20/tambang-banyak-picu-masalah/,diakses tanggal 7 Mei 2018.

${ }^{30}$ Lihat Pasal 1 butir (3) Amandemen ketiga UUD 1945

${ }^{31}$ Lihat sila kelima Pancasila

${ }^{32}$ P. Sondang Siagian, Administrasi Pembangunan (Jakarta : Haji Masagung, 1988) hlm. 104

${ }^{33}$ Teori Vilfredo Pareto, http://resepsigo.blogspot.com/2012/11/teori-vilfredo-pareto.html, diakses tanggal 9 Mei 2018, selanjutnya disebutkan bahwa Pareto menawarkan model masyarakat keseimbangan (homeostatika). Dimana masyarakat yang ditegakkan oleh individu-individu senantiasa mengarah kepada keseimbangan, yaitu pemeliharaan keseimbangan atau pemulihan keseimbangan setelah terjadi pergolakan. Individu-individu saling mempengaruhi, agar suatu keseimbangan tercapai. Hal ini sama kaitannya dengan masyarakat tidak berevolusi dan tidak maju. Oleh karena individu mengadakan relasi lahiriah, dan mereka sendiri tidak berubah, maka masyarakatpun tidak berubah. Seperti efisiensi kerja dan pengorganisasian mungkin di tingkatkan, tetapi itu hanya penyusunan lain dari unsur-unsur yang selalu sudah ada. Pandangan ini disebut the seesaw theory of history. Artinya, masyarakat adalah bagaikan ungkat-ungkit (seesaw), yang selalu mencari keseimbangan antara kedua ujungnya. Hanya keseimbangan yang dicari, bukan
} 
Dengan demikian keberadaan kegiatan pertambangan ditengah masyarakat sosial harus dapat dilihat secara matematis kemanfaatannya bagi semua pihak.Baik itu investor, pemerintah maupun masyarakat itu sendiri. Hal ini setidaknya telah membuka pintu bagi para pihak untuk mengajukan apa yang menjadi terget, keinginan serta kepentingan masing-masing pihak. Sehingga rasionalitas berfikir secara matematis dapat dilakukan untuk menghitung dan mengkalkulasikan apa yang menjadi plus minus masing-masing pihak, upaya ini diharapkan dapat mencapai satu titik keseimbangan dan win-win solution diantara para pihak.

\section{Penutup}

Keberadaan regulasi pertambangan saat ini lebih melihat kepada pertimbangan provit orientied dibandingkan kepada kondisi sosial masyarakat yang terkena dampak dari kegiatan pertambangan tersebut.Regulasi pertambangan lebih banyak mengatur tentang formalitas dan administrasi yang harus dilakukan dan dipenuhi para investor jika ingin melaksanakan kegiatan usaha pertambangan. Namun yang akan terjadi bagi masyarakat serta bagaimana penaggulangannya dan tanggung jawab investor belum menjadi perhatian yang serius dalam regulasi tersebut. Sehingga dapat dikatakan bahwa regulasi pertambangan tidak berpihak kepada kepentingan masyarakat untuk mencapai kesejahterahan sosial, namun lebih berpihak kepada kepentingan investor.

Pengelolaan pertambangan yang begitu rumit dan kompleks tidak menjadi perhatian utama pemerintah dalam pelaksanaannya, hanya sebatas mengeluarkan regulasi dan melaksanakan apa yang diatur sedemikian rupa di dalamnya, keadaan ini sudahdianggap cukup bagi pemerintah dalam mengemban amanah pengelolaan tersebut. Namun dapat kita lihat dan saksikan di daerah-daerah penghasil tambang di Indonesia tidak terlepas dari konflik atas pelaksanaan kegiatan pertambangan tersebut, masyarakat merasakan ketidakadilan dalam pelaksanaan kegiatan pertambangan disekitar wilayah mereka yang terkena dampak. Disatu sisi investasi untuk pembangunan dibutuhkan bagi pembangunan perekonomian nasional, namun disisi lain apakah pemerintah harus menutup mata atas apa yang terjadi di masyarakat dari dampak kegiatan pertambangan tersebut.

perubahan. Memang kadang-kadang terjadi penyusunan kembali atau reshuffle dalam masyarakat, hal mana memberi kesan seolah-olah ada perkembangan dan kemajuan. Apa yang nampaknya perubahan, adalah perpindahan posisi saja sama seperti pada ungkat-ungkit. Ungkat-ungkit sendiri tidak berubah dalam gerak mencari keseimbangan baru. Dalam memperoleh keseimbangan yang mereka harapkan yang dilihat melaui konteks perilaku indvidu, bahwa setiap individu mempunyai perasaan-perasaan otomatis yang aktif menentang setiap hal yang mengancam atau mengganggu kestabilan. Jadi, keseimbangan adalah akibat proses mekanis. Jika perasaan otomatis tersebut tidak ada, tiap usaha merombak atau mengubah sistem sosial, tidak menghadapi perlawanan yang berarti. Masyarakat akan goyah terus menerus, tidak akan memberi kepastian, dan menghancurkan diri sendiri. Akibat adanya "stabilizing forces", yaitu perasaan-perasaan tadi, suatu bentuk atau konfigurasi masyarakat dipertahankan dan pembanggunannya dimungkinkan. Itulah sebabnya, bahwa revolusi dan peperangan pada umumnya bersifat sementara saja. 
Volume 14, Nomor 1, Januari-Juni 2019

\section{Daftar Pustaka}

Bank Indonesia, Survey Faktor-Faktor Nonekonomi Yang Mempengaruhi Iklim Investasi di Sulawesi Selatan Triwulan II-2007, Kajian Ekonomi Regional Sulawesi Selatan.

Boyle, James, The Politic of Reason: Critical Legal Theory And Local Social Thought, University of Pennsylvania Law Review, 1985

Friedman, Lawrence M., Legal Culture and the Welfare State: law and Society-An Introduction. (London:Harvard UniversityPress, 1990

HS, Salim dan Budi Sutrisno, Hukum Investasi di Indonesia, Jakarta : Rajawali, 2008

, Hukum Penyelesaian Sengketa Pertambangan di Indonesia, Bandung : Pustaka Reka Cipta, 2013

Hadi, Sudharto P, Aspek Sosial Amdal. Yogyakarta: Gadjah Mada University Press, 2005

Ilmar, Aminuddin, Hukum penanaman Modal di Indonesia, Jakarta:Kencana Prenada Media Group,2007

Nasution, Bahder Johan, Metode Penelitian Hukum, Bandung : Mandar maju, 2008

Nasution, Bismar, Hukum Kegiatan Ekonomi, Bandung:Book Terace \& Library, 2007 Cet. II

Pertiwi, Hardiyanti Dharma, Dampak Keberadaan Perusahaan Pertambangan Batubara Terhadap Aspek Ekologi, Sosial dan Ekonomi Masyarakat di Era Otonomi Daerah (Kasus: Kelurahan Sempaja Utara, Kecamatan Samarinda Utara, Kota Samarinda). Skripsi: Institut Pertanian Bogor , 2011

Rajagukguk, Erman, Pembaharuan Hukum Indonesia Dalam Era Globalisasi : Suatu Pemikiran Untuk mendorong Pertumbuhan Ekonomi dan Pengentasan Kemiskinan, dalam Agenda Bangsa Pasca 50 Tahun Indonesia Merdeka Jakarta : Cides, 1995

Sembiring, Sentosa, Hukum Investasi, Bandung : Nuansa Aulia, 2010

Siagian, P. Sondang, Administrasi Pembangunan, Jakarta : Haji Masagung, 1988

Sudikno Mertokusumo, Mengenal Hukum (Suatu Pengantar), Yogyakarta:Liberty,1988, Cetakan ke-1

Suhardi, Gunarto, Beberapa Elemenn Penting dalam Hukum Perdagangan Internasional, Yogyakarta : Universitas Atmajaya, 2004

Susmiyati, Haris Retno, Tinjauan Terhadap Permasalahan dalam Pengusahaan Pertambangan Batu Bara di Indonesia, Jurnal Risalah Hukum, Edisi Nomor 2, Desember 2005 
Unger, Roberto M., Teori Hukum Kritis : Posisi Hukum dalam Masyarakat Modern, diterjemahkan dari Law and Modern Society : Toward a Crtitism of Social Teory, Penerjemah : Dariyatno dan Derta Sri Widowatie, Bandung : Nusa Media, 2008. Cet. II

Vagts, Detlev F. Dalam Peranan Hukum dalam Perekonomian di Negara Berkembang.Penyunting : T. Mulya Lubis dan Richard M. Buxbaum, Jakarta : Yayasan Obor Indonesia, 1986. Cet. I

http://walhintt.wordpress.com/2012/05/07/memahami-pertambangan-dampak-dantahapannya/, diakses tanggal 5 April 2018

http://yathh.wordpress.com/2013/06/20/mengenal-dampak-pertambangan-bagimasyarakat-dan-lingkungan-investigasi-lapangan/, diakses tanggal 3 Mei 2018

http://indonesiacompanynews.wordpress.com/2012/02/20/tambang-banyak-picumasalah/, diakses tanggal 7 Mei 2018.

http://resepsigo.blogspot.com/2012/11/teori-vilfredo-pareto.html, diakses tanggal 9 Mei 2018

http://wartawarga.gunadarma.ac.id/2012/01/pelaku-pelaku-ekonomi-dalam-sistemperekonomian-indonesia-3/, diakses tanggal 2 Juni 2018

Undang-undang No. 25 Tahun 2000 tentang Program Pembangunan Nasional Tahun 2000-2004

Undang Undang Nomor 4 Tahun 2009 tentang Pertambangan Mineral dan Batubara

Peraturan Pemerintah Nomor 22 Tahun 2010 tentang Wilayah Pertambangan

Peraturan Pemerintah Nomor 55 Tahun 2010 tentang Pembinaan dan Pemgawasan Penyelenggaraan Pengelolaan Usaha Pertambangan Mineral dan Batubara,

Peraturan Pemerintah Nomor 78 Tahun 2010 tentang Reklamasi dan Pasca Tambang.

Peraturan Pemerintah Nomor 23 Tahun 2013 tentang Pelaksanaan Kegiatan Usaha Pertambangan Mineral dan Batubara

Peraturan Pemerintah Nomor 24 Tahun 2013 tentang Perubahan Atas Peraturan Pemerintah Nomor 23 Tahun 2013 tentang Pelaksanaan Kegiatan Usaha Pertambangan Mineral dan Batubara 